\title{
Conflict between Reality and Illusion in Tennessee Williams' play The Glass Menagerie
}

\section{Pradnya Bhawar}

\author{
M.A. English Student, Savitribai Phule Pune University, Pune, Maharashtra, India
}

Received: 11 Nov 2020; Received in revised form: 01 Dec 2020; Accepted: 06 Dec 2020; Available online: 19 Dec 2020 (C)2020 The Author(s). Published by Infogain Publication. This is an open access article under the CC BY license (https://creativecommons.org/licenses/by/4.0/).

\author{
"How beautiful it is and how easily it can be broken" \\ - $\quad$ The Glass Menagerie
}

\begin{abstract}
The Glass Menagerie is one of the finest plays of Tennessee Williams. It is often thought of as his first major play, because it was this piece that first brought serious critical and public attention to his work when, in 1945, its premiere production became the hit of the theatrical season-initially in Chicago and then in New York. It almost transformed the lifestyle of Williams overnight. It is a phenomenal memory play that won New York Drama Critics Circle Award, Donaldson Award, and Sidney Howard Memorial Award in 1945. To this day, The Glass Menagerie remains the most frequently produced of his plays, and arguably the most popular with the audience.

Tennessee Williams presents before us the dark world of the one-dimensional society of the modern civilization that survives amid exploitation and monetary beliefs. He makes us realize that such worldly circumstances of the tainted world drive the misfits and the rebels to lead lives of dejected madness. It happens due to their failure to adjust to the worldly norms so they create a Utopia through fabricated illusions to feel a sense of freedom. This difficulty the characters have in accepting and relating to reality while they cherish illusions in their lives is the most prominent and urgent theme of the play. The difference between truth and appearance creates an ironic gap and in light of these factors, this essay analyses the theme of conflict between illusion and reality in Tennessee Williams' The Glass Menagerie.
\end{abstract}

Keywords - conflict, distortion, illusion, obligation, reality, Williams.

An illusion is a faulty notion of happiness when life is surrounded by bitter and harsh facts. It is a deceptive appearance that gives false hopes, a world that is fictionalized as a mechanism to survive the truth. The Glass Menagerie centers on the hopes, despairs, predicaments, and failures of the Wingfield family. The Wingfields try to escape from reality to a world of fantasies, dreams, and imagination to forget the pain resulting from a realization of the frustration of actual life, and although this temporary stay in the dream world is pleasant but the return to reality is inevitable. The gap between appearance and reality helps us understand the nature of the illusion in the play.
The play explicitly focuses on the social lives of a family and specific individuals of that family. In fact, what makes this play so peculiarly appealing is that this play is about a family that lives in the shadow of reality. The four main characters of the play include Amanda who is a mother of Laura and Tom and is abandoned by her husband, Laura who is crippled and suffers from social anxiety, and Tom, a young man with dreams who is also burdened by familial obligations at the cost of his dreams. Consequently, the three members of the family become engrossed in their world of illusions, which separates them from the real world. Apart from the Wingfields, there is a fourth character named Jim 
O'Connor or the gentleman caller who is a big part of the illusions created by the Wingfield family.

Characters of this play deliberately try to escape from the actualities of life and live in a Utopia of their own. Amanda, who is a mother to Tom and Laura takes herself to her beautiful past when she used to be courted by several gentlemen callers. She lives her life in constant nostalgia and fabricates stories of her past and imposes them on her children. She constantly escapes to her past to make herself feel better which provides her a temporary solace. She cherishes the illusion of the golden days of her youth, as she exclaims to Tom and Laura, "One Sunday afternoon in Blue mountain - your mother received seventeen! - gentlemen callers". She recalls her comfortable and luxurious days when she was leading an aristocratic life on the plantation. This nostalgic episode provides her with comfort that there was a time when men desired her, in contrast to the fact that she is a woman abandoned by her husband. But this story has been told so often that it is no longer an illusion and instead has become reality. Later she tells Jim O'Conner, "Well in the South we had so many servants. Gone, gone, gone. All Vestige of gracious living! Gone completely! I wasn't prepared for what the future brought me". It proves that she is nostalgically addicted to the past and is not ready to face the reality of her St. Louis tenement. She thinks: 'I am what I was'. Her past was luxurious, almost dreamlike where she was a southern belle, contrasting with her current reality where she is an abandoned wife with two children, living a mediocre life. Tradition, which is the main cause of Amanda's obliviousness to changes in society, is as important to her as her relationship with reality. This makes her retreat back to her past, an illusion where she finds temporary solace from reality.

Amanda is caught up in the illusion of her genteel old southern upbringing, which has taught her that a man will support a woman and that there are certain foolproof rules for snagging one. Her experience, however, proves this to the contrary- specifically when her husband runs out of the family and leaves her to fend for herself and later when Laura's shyness prevents her from normal socialization. For Amanda, being abandoned by her husband means being abandoned by her childhood understanding of men and the world. Still, she never stops believing that a gentleman will soon call upon her children - insisting that if Tom finds a husband for Laura, it will take care of all their problems. The idea that Tom can solve all their problems with a replacement is itself an illusion, one that is quickly eradicated by the reality once he brings home a caller for Laura.

Although Amanda lives in illusions, she can never overlook the dingy reality of St. Louis. She is the one person who is trying to keep her family together after her husband's desertion. She is a delusional romantic turned realist. Unlike other characters, Amanda is partial to real-world values and longs for social and financial success, and her attachment to these values is exactly what prevents her from perceiving many truths about her life. She cannot accept that she is or should be anything other than the pampered belle she was brought up to be. Her retreat into illusion is in many ways more piteous than her children because it is not a willful imaginative construction but a wistful distortion of reality.

Laura Wingfield is another lead character in the play who presents the movement from illusion to reality. She is a complete illusion-ridden character at the beginning of the play but she comes in contact with reality for a short while and again surrenders to the illusions. Laura is out of place, a misfit in the real world because of her shyness and sensitivity, and her limp does not make it any easy. Her world is surrounded by phonograph records and glass animals that are fragile like her. She retreats to the world of her imagination, peopled by music and glass animals.

For Laura, dreams do not take the form of ambition, but instead, offer her a refuge from the pain of reality. Unlike her mother, Laura does not delude herself by pretending that her disabilities do not exist. Instead, she retreats from the world by surrounding herself with perfect, immortal objects like her glass menagerie and the jewel box she visits. Laura's ties to her make-believe world are as strong as Amanda's is to her past. Her oversensitive nature makes her think that everyone notices her limp, it becomes a huge hurdle to normal living, and her inability to overcome this defect causes her to withdraw into her world of illusions. Her physical condition thus represents her mental distress, she is crippled both mentally and physically. In search of companionship, she builds her fantasy world with her glass animals, a Victrola, and old records.

Although Laura is the only character who appears to be most divorced from reality, she is also the only one who is in touch with the truth about herself. Unlike Tom, who thinks of her as a cherished possession, and Amanda who refuses to recognize her daughter's disabilities, Laura understands her limitations and accepts them. She accepts the reality of her physical limitations and uses illusions to survive. 
Laura forces herself to be led by illusions but when the unicorn breaks and all hopes are shattered her world of illusion collapses and reality hits hard. For a short while, she comes in contact with reality in the last scene where she comes out of her shell of illusions with help of Jim. When Jim observes that Laura's main problem is her lack of confidence in herself, he tries to instill confidence in her by telling her to think of herself as superior in some way. He tries to encourage and uplift her spirits by saying that she is unique. He is the one who forces her to see the reality of life. Laura contrasts with the normal, middle-class, realistic Jim whom she dreamily falls in love with. He is so different from her world of illusions that he appears to be the knight in shining armor, which is yet another illusion. But when Jim breaks her heart, Laura does not have to retreat into her world because she has never left it sufficiently enough to necessitate the retreat. Quite the contrary, now that the unicorn is broken, is ordinary like Jim. She sends it forth with him and she remains in her unique world with the other unique glass animals.

Tom Wingfield is one of the foremost characters in the play who is also illusion ridden and represents the theme of movement from illusion to reality. $\mathrm{He}$ is a potentially creative character caught in a conventional and materialistic world. His job and financial obligation have clipped the wings of his romanticism and adventure. He tells his mother, "I am leading a double life, a simple honest warehouse worker by day, by night a dynamic Tsar of the underworld". What he has to do is the reality of his life and what he intends to do are his dream and fantasy. Being unable to have any worldly success he lives in the world of movies to escape from the realities of life.

In scene one, Tom enters, dressed as a merchant sailor, and strolls across to the fire escape where he stops and lights a cigarette and addresses the audience. "Yes, I have tricks in my pocket. I have things up my sleeve. But I am the opposite of a stage magician. He gives you an illusion that has the appearance of truth. I give you the truth in the pleasant disguise of illusion". This monologue introduces a major source of tension and conflict in the play - the complex relationship between illusion and reality where illusions contradict reality but they also make reality bearable.

Tom is a character of conflict. His ambitions and hopes for the future give him the motivation he needs to leave his family just like his father. He thinks that he will be able to discover himself in the world of adventure and travel. $\mathrm{He}$ harbors the illusion that by joining the Merchant marine and

ISSN: $2456-7620$ sailing to all parts of the world, he would be able to discover himself. He is caught in a conventional and materialistic world. He has his independent world which provides him solace and is composed of those things he considers important - his poetry, his dreams, his freedom, his adventures, and his illusions. All these things are in direct contrast to his mother's expectations of him. His conflict is between his world of dreams and the real world.

Tom is every bit the romantic his mother is, although he does not realize it. He sees himself as a poet, as an artist whose soul is stifled by his warehouse existence. As Amanda is stuck in the past, Tom survives only on dreams of the future, ironically failing to realize his goals and the satisfaction he covets by dismissing his relationships and work obligations.

Tom is consumed by his mother and sister's world of illusion, deception, and withdrawal which makes him sought an escape of his own by watching movies and writing poetry. But he soon realizes that he is watching adventures rather than living them and that they are a momentary psychological escape to a world of illusions. The movie is only an illusionary step that in reality, is hard to accomplish. Tom contended that "man is by instinct' a lover, a hunter, and a fighter". These are the qualities that Amanda's husband possessed and she refuses to recognize these qualities as decent. Therefore, Tom could only recognize his instinctual drives by leaving home and sets off to turn his illusions into reality. This power of turning his illusions into reality is what sets Tom apart from the rest of the characters. This decision is made with the awareness of the inevitable clash between illusion and reality, reaction and action, and what life has given him and what he can control.

Apart from the three main characters, Jim O'Conner is another character who contributes to depict the theme of movement from illusion to reality in the play. Tom describes Jim as "The most realistic character in the play, being an emissary from a world of reality that we were somehow set apart from". Jim enters the play as a ray of hope for the Wingfield family. He is their pass to normal lives, he is the person who would turn their illusions into reality.

The ordinary aspect of Jim's character seems to come to life in his conversation with Laura, but it is the contact with reality that Laura needs. Thus, it is not surprising that the ordinary seems to Laura to be the essence of magnificence. But Jim's function in the play is more important than his seemingly ordinary character would allow. Since Laura lives 
in a world of illusion and dreams, Jim, as the ordinary person, seems to Laura to be wonderful and exceptional. He is so different from her world that he appears to be the knight in shining armor, yet another of her illusions.

Although Tom describes Jim as the most realistic character, Jim harbors the illusion of the American Dream that he can become anything in his life. It is the 'rags to riches' path of nineteenth-century America. He labors under the delusion that by taking a course in radio engineering, he would be able to get into the television industry and reach the top. Unlike the Wingfields, Jim neither lives in a dream world of the past nor a secret future dream life, but in the present. And yet Jim is himself hoping for a career in the radio and television industry that might be described as being in the business of creating dreams or believable illusions and in this way, the play suggests that the Wingfield's are not alone in their susceptibility to dreams, he must be protected by illusions from a harsh world that prevents individual fulfillment.

There is an unseen character in the play who does not appear on the screen except in his larger than life photograph over the mantle. He is Amanda's husband who abandons his family to pursue his dreams and ambitions, leaving Amanda to fend for herself and raise her children alone. He does not appear in the play, but his character plays an important role in demonstrating and accentuating Amanda's blindness to reality. Mr. Wingfield was a typical gentleman caller who once pleased Amanda with his charms and later married. He was also an irresponsible pleasure seeker who deserts his family for his selfishness, announcing the death of the marriage and challenges the credibility of the gentlemen caller tradition.

Tom says about him, "He was a telephone man who fell in love with long distances... The last we heard of him was a picture postcard from Mazatlan, on the Pacific coast of Mexico, containing a message of two words: 'Hello Goodbye!' and no address". Tom and Laura's father was illusion-ridden, he deserts his family for the sake of his adventure, and for the love of long distances and faraway lands, he leaves his family in the lurch to fend for themselves. Tom shares similar interests as his father, he has the same love for adventure and the need to run away from the mediocre life he has been living. Mr. Wingfield was so tired of reality that he does not even leave his address for his family in the last postcard he sent. Amanda realizes that her son has inherited the same qualities as his father and worries that he too might abandon them. This fear of abandonment

ISSN: $2456-7620$

https://dx.doi.org/10.22161/ijels.56.50 makes her controlling and dominating. But the difference between father and son is that the father could break the bonds of his family without any guild but Tom could not shatter the shackles of his family. Although Tom ends up abandoning his family like his father, the guilt of his actions haunt him forever.

Tennessee Williams, through this play, shows us that the various illusions that the characters have are the means of coping with the facts of their lives. However frivolous and foolish their illusions may seem, all the characters of the play would suffer, perhaps even be broken, if they are deprived of them. Without the pretense and delusion, Amanda would have no hope for the future. Laura would wither and die because she could not identify herself with anything, nor see beauty, delicacy, and truth in small, fragile things like herself. Tom would not escape because he could not hope to experience change and adventure and would simply survive in the world rather than living it. Jim would not have the hope for his future after he fails to attain the peak of success that people believed he would have. Without a doubt, illusion provides a shield to the characters that might otherwise be crushed or doomed.

Though the play is overwhelmingly nonrealistic, its content is a different matter. The play, as Tom says, is committed to giving its audience "truth in the pleasant disguise of illusion". This ironic gap between illusion and reality and the characters' struggle makes this play one of its kind. Though escaping into the world of illusions is not a reliable solution, the characters find a remedy for the sickness of life.

\section{CONCLUSION}

Tennessee Williams depicts that life is a mixture of illusions and facts. Sometimes the illusions give a better relief to a frustrated man. He tries to express his ideas of reality as a harsh but inevitable truth that everyone wants to avoid and illusion as a defense and deviation from the bitter and harsh reality of life. But these illusions are simply a survival mechanism for the characters in the play. Without these illusions, they cannot survive the dingy realities of their lives and will be crushed. As their stay in the world of illusions can help them to temporarily forget the aches and pains of life, the illusions sound pleasant. Williams has succeeded in prompting us to think along the line by dramatizing the conflict between reality and illusion. No matter how pleasant 
the world of illusion may be, one cannot, however, turn ones back completely on reality for long.

The Glass Menagerie is not a play focusing only on social issues, as the philosophical and even mythical nature of Williams' work can be even more frightening than its social content. He strongly suggests to the modern world through his characterization that no one can escape reality by simply taking off in the flight of illusion. He speaks to us about the loneliness of modern life, the tendency of individuals to approach alienation, and withdrawal from ultimate questions and facts and finally shows us that the so-called survival mechanisms the family decided to rely on were transformed into destructive power. The Glass Menagerie identifies the conquest of reality by illusion as a huge and growing aspect of the human condition in its time.

\section{REFERENCES}

[1] Atkinson, Brooks. New Voices in the American Theatre. New York: The Modern Library, 1955. Print.

[2] Baym, Nina (Ed.). The Norton Anthology of American Literature. Eight Edition: Volume E. W.W. Nortan\& Company. New York. 2012. Print.

[3] Bloom, Harold, ed. The Glass Menagerie: Modern Critical Interpretations. New York: Chelsea House, 1988. Print.

[4] Bottoms, Stephen, ed. The Glass Menagerie. Tennessee Williams. Bloomsbury Publication. New Delhi. 2015.

[5] Davis, Joseph K. "Landscapes of the Dislocated Mind in Williams, The Glass Menagerie." Tennessee Williams: A Tribute. Ed. Jac Tharpe. Jackson: UP of Mississippi, 1977. 192-206. Print.

[6] Huges, Catherine R. Tennessee Williams: A Biography. Englewood Cliffs, N.J.:Pretice-Hall,Inc.,1978. Print.

[7] Singh, Bhim. MIT International Journal of English Language \& Literature, Volume 2, Number 1, January 2015, pp.67-70. MIT Publication. Print. 